Klinička psihologija 12 (2019), 1-2, 39-65

Izvorni znanstveni rad - UDK

DOI: 10.21465/2019-KP-1-2-0003

\title{
ODNOS ZADOVOLJSTVA TIJELOM, ZADOVOLJSTVA ROMANTIČNOM VEZOM I KOMENTARA PARTNERA/ICE O TJELESNOM IZGLEDU
}

\author{
Dora Herkov \\ Osnovna škola Sunja \\ Ljudevita Posavskog 55a, 44210 Sunja \\ dora.herkov@skole.hr \\ Inja Erceg \\ Sveučilište u Zagrebu, Filozofski fakultet, Odsjek za psihologiju \\ Ivana Lučića 3, 10000 Zagreb \\ inerceg@ffzg.hr
}

\begin{abstract}
Sažetak
Cilj ovog istraživanja bio je ispitati spolne razlike u izraženosti zadovoljstva tijelom, važnosti slike tijela i čestini dobivanja pozitivnih i negativnih komentara o tjelesnom izgledu od partnera/ice te provjeriti prediktivnost nekih bioloških i psiholoških varijabli te varijabli vezanih uz romantičnu vezu u objašnjavanju zadovoljstva tijelom. U istraživanju je sudjelovao 371 sudionik (74,7\% ženskog spola), dobnog raspona od 18 do 54 godine $(M=24,7 ; S D=5,07)$. Podaci su prikupljani online metodom, primjenom seta upitnika za mjerenje zadovoljstva tijelom i romantičnom vezom, važnosti slike tijela te pozitivnih i negativnih komentara partnera/ice o tjelesnom izgledu. Rezultati istraživanja pokazuju kako između muškaraca i žena ne postoji razlika u zadovoljstvu tijelom, kao ni u važnosti koju pridaju slici tijela. Iako podjednako često dobivaju pozitivne komentare svojih partnera/ica, muškarci češće dobivaju one negativne. Hijerarhijskom regresijskom analizom utvrđeno je kako su kod žena manja željena promjena tjelesne težine i pozitivni komentari partnera/ica o njihovu tjelesnom izgledu značajni pozitivni prediktori zadovoljstva tijelom, dok je kod muškaraca varijabla negativni komentari partnera/ice o tjelesnom izgledu značajan negativni prediktor zadovoljstva tijelom.
\end{abstract}

Ključne riječi: zadovoljstvo tijelom, važnost slike tijela, zadovoljstvo romantičnom vezom, komentari partnera o tjelesnom izgledu, tjelesna težina. 


\section{UVOD}

Savršena tijela medijski eksponiranih osoba, opsjednutost društva ljepotom i mladošću te naglašavanje poželjnosti ženske mršavosti ili pak mišićavosti muškoga tijela pridonose tome da zadovoljstvo sobom uvelike počiva na tjelesnom izgledu te da je nezadovoljstvo tijelom, zbog svoje učestalosti, postalo gotovo uobičajeno (Gondoli, Corning, Blodgett Salafia, Bucchianeri i Fitzsimmons, 2011; Paxton, Norris, Wertheim, Durkin i Anderson, 2005). Unatoč svjesnosti o nedostižnosti nametnutih ideala tjelesnog izgleda, ipak im se nastojimo približiti, što može narušiti i iskriviti sliku vlastitog tijela (Thompson, Heinberg, Altabe i Tantleff- Dunn, 1999).

\section{Slika tijela i nezadovoljstvo tijelom kod osoba oba spola}

Slika tijela je višedimenzionalan konstrukt koji se odnosi na subjektivnu percepciju vlastitog tjelesnog izgleda, ali i na stavove koje pojedinac ima o njemu (Cash, Morrow, Hrabosky i Perry, 2004; Cash, Thériault i Annis, 2004). Sastoji se od dvije komponente: perceptivne i subjektivne. Perceptivna komponenta odnosi se na točnost procjene veličine, oblika i težine vlastitog tijela u odnosu na stvarne proporcije te se određuje na razini tijela u cjelini ili njegovih specifičnih dijelova (Banfield i McCabe, 2002), dok se subjektivna komponenta odnosi na doživljaje (ne)ugode i (ne)zadovoljstvo veličinom ili oblikom tijela te uključuje stavove koji mogu biti vezani uz tjelesni izgled u cjelini ili uz pojedine dijelove tijela i/ili tjelesne karakteristike (Gardner, 2002).

Jedan od aspekata slike tijela je nezadovoljstvo tijelom koje se odnosi na negativnu subjektivnu procjenu vlastitog tjelesnog izgleda (Juarez i Pritchard, 2012), a do njega dolazi kad postoji raskorak između percipiranog i željenog tjelesnog izgleda (Gardner, Friedman, Stark i Jackson, 1999). Nezadovoljstvo tijelom prediktor je mnogih poremećaja hranjenja te s tjelesnom težinom povezanih problema poput čestih restriktivnih dijeta, kompenzacijskih strategija nakon unosa hrane ili pokušaja dobivanja na težini (Bucchianeri, Arikian, Hannan, Eisenberg i Neumark-Sztainer, 2013). S obzirom na sve veću prevalenciju nezadovoljstva tijelom, ne čudi što je to sve češće istraživana tema (Erceg Jugović, 2011). Iako su istraživanja (ne)zadovoljstva tijelom bila većim dijelom usmjerena na žensku populaciju zbog nalaza da su žene nezadovoljnije svojim tjelesnim izgledom te da je prevalencija nezadovoljstva tijelom i s njime povezanih problema prilagodbe veća među djevojkama i ženama (Goins, Markey i Gillen, 2012), činjenica da je sve više muškaraca opterećeno svojim tjelesnim izgledom potaknula je interes za istraživanje (ne)zadovoljstva tijelom i kod muškog spola (Tager, Good i Morrison, 2006). Premda je nezadovoljstvo tijelom kod žena, i ono kod muškaraca, potrebno razmatrati u različitim psihosocijalnim kontekstima, ono može dovesti do jednako ozbiljnih psihosocijalnih ili zdravstvenih posljedica kao što su poremećaji hranjenja, korištenje raznih suplemenata i/ 
ili dodataka prehrani, steroida te pretjeranog vježbanja (Babarović, 2017; McCabe i Ricciardelli, 2004).

U novije se vrijeme muško tijelo, u odnosu na prošla desetljeća, prikazuje mršavijim i mišićavijim (Goins i sur., 2012). Muškarci se trude izgraditi što mišićavija tijela kako bi dostigli navedene ideale, a što može uključivati i povećanje i gubitak tjelesne težine (Shelton i Liljequist, 2002). Dugogodišnji trend u ženskoj ljepoti je mršavost (Arroyo i Harwood, 2012; Mills i Fuller-Tyszkiewicz, 2016; Weller i Dziegielewski, 2005). Međutim, istraživanja pokazuju da očekivanja vezana za tjelesne atribute ili, pak, atletske građe tijela ne odgovaraju samo idealu mršavosti budući da žene, osim mršavosti, teže i definiranim čvrstim mišićima (Weller i Dziegielewski, 2005). Kako bi postigle spomenute ideale, žene se najčešće okreću restriktivnim dijetama i redukciji unosa hrane kako bi izgubile na tjelesnoj težini (Shelton i Liljequist, 2002). Međutim, kao što je navedeno, izgrađeni i čvrsti mišići danas postaju sve važniji kod osoba oba spola.

Tjelesna težina, indeks tjelesne mase i zadovoljstvo romantičnom vezom

Jedan od čimbenika koji snažno utječe kako na ženinu, tako i na muškarčevu sliku tijela jest indeks tjelesne mase (ITM; BMI, Body Mass Index, engl.), statistički pokazatelj tjelesne težine u odnosu na tjelesnu visinu. Prema klasifikaciji Centra za kontrolu i prevenciju bolesti (2012; prema Blodgett Salafia i Benson, 2013) te klasifikaciji Svjetske zdravstvene organizacije (2018), ITM niži od 18,5 upućuje na pothranjenost, raspon između 18,5 i 24,9 na normalnu/idealnu tjelesnu težinu, ITM veći od 25 na prekomjernu tjelesnu težinu, dok onaj iznad 30 upućuje na pretilost. Prenizak ili visok ITM može dovesti do većeg pritiska okoline da osoba dobije ili izgubi na tjelesnoj težini, što može voditi do nezadovoljstva tijelom (Luciano, 2007; Stice, 2002). Kako kod žena, tako i kod muškaraca, tjelesna težina utječe na zadovoljstvo tjelesnim izgledom. Međutim, kod žena je tjelesna težina jedan od najvažnijih čimbenika koji utječe na njihovo mišljenje o vlastitom tijelu (Dalley, Pollet i Vidal, 2013). Također, žene čiji partneri imaju niži ITM od njihova, opterećenije su vlastitim izgledom od žena koje imaju isti i/ili niži ITM od svog partnera (Markey i Markey, 2011).

Rezultati istraživanja o vezi ITM-a i zadovoljstva romantičnom vezom nisu u potpunosti sukladna. Naime, prema rezultatima nekih istraživanja, povezanost ITMa i zadovoljstva romantičnom vezom ne postoji (Markey i Markey, 2006; Meltzer, McNulty, Novak, Butler i Karney, 2011), dok druga pronalaze postojanje pozitivne povezanosti ITM-a i zadovoljstva romantičnom vezom (Meltzer i sur., 2011; Sheets i Ajmere, 2005). Ipak, većina istraživanja zadovoljstva romantičnom vezom pokazuju kako je ženina tjelesna težina i ITM važan čimbenik kvalitete i zadovoljstva romantičnom vezom te da postoji negativna povezanost ITM-a sa zadovoljstvom romantičnom vezom, odnosno da su mršavije žene i njihovi partneri sretniji u ro- 
mantičnoj vezi u odnosu na žene s višom tjelesnom težinom i njihove partnere (Boyes i Latner, 2009; Meltzer i sur., 2011; Sheets i Ajmere, 2005). Zadovoljstvo romantičnom vezom je i kod žena i kod muškaraca manje kada je žena ta koja ima viši ITM u odnosu na svog partnera (Burke, Randall, Corkery, Young i Butler, 2012; Meltzer i sur., 2011). Međutim, osim navedenog, čak i neovisno o partnerovu ITM$\mathrm{u}$, žene s nižim ITM-om zadovoljnije su romantičnom vezom u odnosu na žene s višim ITM-om koje su, osim što su nezadovoljnije romantičnom vezom, izložene i većoj vjerojatnosti prekida romantične veze (Boyes i Latner, 2009; Burke i sur., 2012; Sheets i Ajmere, 2005). Međutim, potrebno je napomenuti kako ITM ne daje točne podatke o postotku tjelesne masnoće i/ili mišića u tijelu jer u obzir uzima samo podatke o tjelesnoj visini i tjelesnoj težini (Blodgett Salafia i Benson, 2013).

Uloga partnerovih/ičinih komentara o tjelesnom izgledu i zadovoljstva romantičnom vezom u zadovoljstvu tijelom

Jedan od važnih čimbenika koji utječe na sliku tijela i zadovoljstvo tijelom su romantični partneri/ice (van den Brink, Smeets, Hessen i Woertman, 2016). Istraživanja pokazuju kako iskustva u romantičnoj vezi mogu utjecati na ženino zadovoljstvo vlastitim tijelom (Markey i Markey, 2006; Weller i Dziegielewski, 2005). Međutim, nalazi istraživanja nisu potpuno konzistentni. Različiti nalazi mogu proizlaziti iz činjenice da na zadovoljstvo tijelom ne utječe samo bivanje u romantičnoj vezi, već i njena kvaliteta i kvaliteta komunikacije između partnera, posebice komentara koje partneri upućuju jedan drugome. Naime, neka istraživanja pronalaze kako su žene koje su u romantičnoj vezi zadovoljnije svojim tijelom (Blodgett Salafia i Benson, 2013; Forbes, Jobe i Richardson, 2006), druga nalaze da su one češće njime nezadovoljne (Compian, Gowen i Hayward, 2004; Sheets i Ajmere, 2005), dok treća ne pronalaze povezanost između statusa veze i zadovoljstva tijelom (Paxton i sur., 2005).

Iako je malo empirijskih nalaza o ulozi komentara romantičnih partnera/ica o izgledu (Carriere i Kluck, 2014), neka istraživanja pokazuju da tijekom adolescencije i mlađe odrasle dobi, posebice u zapadnoj kulturi, romantični partneri imaju pritom snažan utjecaj i da su važan izvor informacija o samome sebi uključujući i onih o izgledu tijela (Goldsmith i Byers, 2016). Komentari o tjelesnom izgledu romantičnih partnera mogu utjecati na to što pojedinac misli o sebi (Murray, Holmes i Griffin, 1996) zbog čega je važno razmotriti utjecaj komentara o tjelesnom izgledu partnera kao jednog od mogućih rizičnih čimbenika za razvoj negativne slike tijela i nezadovoljstva tijelom (Evans i Stukas, 2007). Žene i muškarci će podjednako često komentirati partnerovu tjelesnu težinu i tjelesni izgled, no čini se kako postoje razlike u prirodi takvih komentara: žene će češće poticati muškarce na dobivanje na tjelesnoj težini, dok će muškarci češće poticati žene na mršavljenje (Sheets i Ajmere, 2005). 
Iako neki istraživači pronalaze kako negativni komentari romantičnih partnera mogu utjecati i/ili dovesti do nezadovoljstva tijelom (Weller i Dziegielewski, 2005), neka istraživanja ne pronalaze povezanost komentara partnera i (ne)zadovoljstva tijelom (Bond i McDowell, 2001). Naime, iako žene izjavljuju da žele izgubiti na tjelesnoj težini, što može upućivali na određeno nezadovoljstvo tijelom, njihovi pokušaji mršavljenja nisu povezani s negativnim komentarima njihovih partnera o tjelesnom izgledu (Bond i McDowell, 2011). Ipak, i žene i muškarci se osjećaju bolje i zadovoljniji su svojim tjelesnim izgledom kada vjeruju da je njihovim izgledom zadovoljan i njihov partner (Brown, Stukas i Evans, 2013; Goins i sur., 2012; Goldsmith i Byers, 2016; Weaver i Byers, 2006). Stoga ne čudi što negativni komentari partnera mogu pridonijeti većem nezadovoljstvu tjelesnim izgledom, dok podržavajuća komunikacija i podrška između partnera može smanjiti nezadovoljstvo vlastitim izgledom (van den Brink i sur., 2016; Weller i Dziegielewski, 2005).

Pokazalo se da je jedan od razloga zbog kojeg su žene s većom tjelesnom težinom nezadovoljnije kvalitetom romantične veze negativna evaluacija koju dobivaju od svojih partnera, odnosno njihova izloženost negativnim komentarima o izgledu, što dovodi do većeg nezadovoljstva tijelom, a što je posebice izraženo kod djevojaka u razdoblju adolescencije (Compian i sur., 2004; Sheets i Ajmere, 2005). Negativan komentar o tjelesnom izgledu, osim što utječe na zadovoljstvo tijelom, dovodi i do nezadovoljstva romantičnom vezom (Pole, Crowther i Schell, 2004).

Nadalje, žene vjeruju da ih muškarci vide negativnije nego što je to doista tako, a to vodi do veće opterećenosti time što muškarci misle o ženskom tijelu (Markey, Markey i Birch, 2004). Pokazalo se da je ono kako partneri stvarno vide svoju partnericu manje važno od njene percepcije toga kako je partner vidi (Goins i sur., 2012). Žene, u odnosu na muškarce, osjećaju veći pritisak za održavanjem privlačnog tjelesnog izgleda, čak i nakon što nađu partnera. Također, naročito one koje su u dužoj romantičnoj vezi, pogrešno vjeruju da njihovi partneri žele da su mršavije, odnosno vjeruju da su njihovi partneri s vremenom sve manje zadovoljni njihovim tjelesnim izgledom te da će svom partner biti manje privlačne ako se udebljaju, iako rezultati istraživanja to ne potvrđuju (Markey i Markey, 2006; Sheets i Ajmere, 2004). Druga istraživanja su pokazala da su osobe koje su duže u romantičnoj vezi zadovoljnije vlastitim tijelom, odnosno da dužina veze smanjuje opterećenost vlastitim izgledom i da umanjuje utjecaj nerealnih ideala o tjelesnom izgledu (Tom, Chen, Liao i Shao, 2005).

Osim toga, kada zadovoljavaju partnerove/ičine ideale i standarde, muškarci i žene su zadovoljniji i vlastitim tjelesnim izgledom, ali i romantičnom vezom. Empirijska istraživanja pokazala su da čak i nerealistični pozitivni stavovi o partneru mogu pridonijeti zadovoljstvu romantičnom vezom (Evans i Stukas, 2007).

Muškarci i žene češće dobivaju pozitivne nego negativne povratne informacije o vlastitom izgledu, a svakodnevna komunikacija između partnera, koliko god se činila neutralnom, može imati snažan utjecaj na pojedinca (Goldsmith i Byers, 2016). Naime, iako primamo više neverbalnih nego verbalnih informacija u svakodnevnoj 
komunikaciji, moguće je da verbalne poruke imaju snažniji utjecaj te da ih lakše pamtimo jer su eksplicitnije od neverbalnih. Također, pojedinci čak i porukama koje nisu eksplicitne pripisuju pozitivan ili negativan prizvuk, što je češći slučaj s neverbalnim porukama budući da one ostavljaju više prostora za interpretaciju (Goldsmith i Byers, 2016; Lamer, Reeves i Weisbuch, 2015). Još jedan razlog zbog kojeg partnerovi/ičini komentari o tjelesnoj težini drugog partnera/ice mogu smanjiti zadovoljstvo romantičnom vezom je selektivno pamćenje. Moguće je da osobe nezadovoljne svojom vezom češće percipiraju i pamte negativne komentare koje im partner/ica uputi (Sheets i Ajmere, 2004).

Cilj ovog istraživanja bio je ispitati spolne razlike u izraženosti zadovoljstva tijelom, važnosti slike tijela i čestini dobivanja pozitivnih i negativnih komentara o tjelesnom izgledu od partnera/ice te provjeriti doprinos nekih bioloških i psiholoških varijabli, poput spola, dobi, željene promjene tjelesne težine, važnosti slike tijela, te varijabli vezanih uz romantičnu vezu, poput statusa i dužine veze, zadovoljstva vezom, komentara partnera/ice o tjelesnom izgledu i važnosti koju partner/ ica pridaje tjelesnom izgledu svog/svoje partnera/ice u objašnjavanju zadovoljstva tijelom.

\section{METODA}

\section{Sudionici}

Istraživanje je provedeno na uzorku od 401 sudionika, korisnika društvenih mreža koji su trenutačno u vezi ili su vezu prekinuli prije najviše jednu i pol godinu. Iz daljnje obrade izuzeti su rezultati 30 sudionika. Naime, dio sudionika nikada nije bio u romantičnoj vezi $(n=5)$, dok je kod dijela sudionika proteklo više od jedne i pol godine od posljednje romantične veze zbog čega su isključeni iz daljnje obrade $(n=25)$. Kriterij od jedne i pol godine je korišten zbog pretpostavke da sudionici i koji nisu trenutačno u vezi, ali su u njoj bili, mogu i nakon više od godine dana od prekida osjećati posljedice komentara svojih partnera/ica o njihovu tjelesnom izgledu. Sve statističke analize provedene su na odgovorima 371 sudionika. Od 371 sudionika, 277 je ženskog spola $(74,7 \%)$ dobnog raspona od 18 do 54 godine $(M=$ $24,7 ; S D=5,07)$.

Mjerni instrumenti

\section{Ljestvica Zadovoljstvo tijelom}

Za potrebe ovog istraživanja korištena je prilagođena i izmijenjena ljestvica Zadovoljstvo tijelom iz Inventara slike tijela i promjene tjelesnog izgleda (Body Image and Body Change Inventory; Ricciardelli i McCabe, 2002), prvi puta kori- 
štena u istraživanju Erceg Jugović (2015). Ljestvica se sastoji od 14 čestica koje mjere aspekte zadovoljstva tijelom i zadovoljstvo izgledom pojedinih dijelova tijela. Sudionici odgovaraju na skali Likertova tipa (od $1=$ jako nezadovoljan/na do 5 = jako zadovoljan/na). Ljestvica pruža mogućnost dobivanja pojedinačnih rezultata o zadovoljstvu tjelesnom težinom i visinom, oblikom tijela, veličinom, snagom te čvrstoćom mišića, a teorijski raspon rezultata kreće se od 1 do 5. Također, moguće je izračunati ukupni rezultat općeg zadovoljstva tijelom, a izračunava se kao jednostavna linearna kombinacija procjena sudionika na svih 14 čestica pri čemu se teoretski raspon rezultata kreće od 14 do 70 . Viši rezultat upućuje na veće opće zadovoljstvo tijelom ili zadovoljstvo pojedinim tjelesnim aspektom. Za potrebe ovog istraživanja korišten je ukupni rezultat koji predstavlja mjeru općeg zadovoljstva tijelom. Primjer čestice za zadovoljstvo tijelom je: "Koliko si zadovoljan/na svojom težinom?" Pouzdanost tipa unutarnje konzistencije na našem uzorku iznosi $\alpha=, 88$.

\section{Ljestvica Važnost slike tijela}

Prevedena i prilagođena ljestvica Važnost slike tijela iz Inventara slike tijela i promjene tjelesnog izgleda (Body Image and Body Change Inventory; Ricciardelli i McCabe, 2002) je kao i prethodna ljestvica prvi put korištena u istraživanju Erceg Jugović (2015). Ljestvica sadrži 14 čestica koje mjere koliku važnost osoba pridaje pojedinim aspektima tjelesnog izgleda te koliku važnost osoba pridaje izgledu pojedinih dijelova svoga tijela. Sudionici odgovaraju na skali Likertova tipa (od $1=$ uopće nije važno do $5=$ jako važno). Kao i prethodna ljestvica i ova nudi mogućnost dobivanja pojedinačnih rezultata o važnosti tjelesne težine i visine, oblika tijela, veličine, snage te čvrstoće mišića pri čemu se teorijski raspon rezultata kreće od 1 do 5, ali i mogućnost izračunavanja ukupnog rezultata koji je mjera opće važnosti slike tijela, a izračunava se kao jednostavna linearna kombinacija procjena sudionika na svih 14 čestica. Teoretski raspon rezultata kreće se od 14 do 70. Viši rezultat upućuje na veću važnost koju osoba pridaje svom tjelesnom izgledu ili nekom njegovu aspektu. Za potrebe ovog istraživanja korišten je ukupni rezultat koji je mjera opće važnosti slike tijela. Primjer čestice za važnost slike tijela je: "Koliko ti je važna veličina tvojih mišića?" Pouzdanost tipa unutarnje konzistencije na našem uzorku iznosi $\alpha=, 84$.

\section{Percipirana kvaliteta romantične veze}

Kvaliteta romantične veze procijenjena je upitnikom Percipirana kvaliteta romantične veze (Perceived Relationship Quality Components; Fletcher, Simpson i Thomas, 2000). Upitnik sadrži 18 čestica koje mjere šest faceta romantične veze. Faktori upitnika su: zadovoljstvo, odanost, intimnost, povjerenje, strast i ljubav. Sudionici na svaku česticu odgovaraju na skali od sedam stupnjeva: od $1=$ uopće ne do $7=\mathrm{u}$ potpunosti. Čestice su bile prilagođene statusu veze sudionika (npr. "Koliko ste zadovoljni svojom vezom?" za one koji su trenutačno u vezi, odnosno "Koliko 
ste bili zadovoljni svojom vezom?" za sudionike koji trenutačno nisu u vezi). Za potrebe ovog istraživanja korišten je ukupni rezultat koji predstavlja mjera percipirane kvalitete romantične veze.

\section{Upitnik komentara partnera/ice o tjelesnom izgledu}

Upitnik komentara partnera/ice o tjelesnom izgledu konstruiran je za potrebe ovog istraživanja djelomično se temeljeći na već prilagođenom upitniku VCOPAS-P (Verbal Commentary on Physical Appearance Scale - VCOPAS; Herbozo i Thompson, 2006), koji su Carriere i Kluck (2014) modificirali kako bi mjerio pozitivne i negativne komentare partnera/ice o tjelesnom izgledu. S obzirom na to da je verzija prilagođenog upitnika sadržavala čestice koje se odnose samo na žene, dio čestica je modificiran kako bi bio primjenjiv i relevantan i za muške sudionike.

Prilagođeni upitnik korišten u ovom istraživanju mjeri čestinu partnerovih/ičinih komentara o tjelesnom izgledu te se sastoji od 26 čestica pri čemu sudionici odgovaraju na skali Likertova tipa (od $1=$ nikad do $5=$ gotovo uvijek). Faktorska struktura ispitana je analizom glavnih komponenata s oblimin rotacijom. Kao kriterij za zadržavanje faktora korišteni su Guttman-Kaiserov kriterij te Catellov scree test. Ekstrahirana su dva faktora, a rezultati faktorske analize čestica ljestvice prikazani su u Prilogu 1. Dva dobivena faktora objašnjavaju ukupno 52,8\% varijance. Prvi faktor zasićen je sa 16 čestica, dok se unutar drugog faktora grupiralo 10 čestica. Analizom sadržaja čestica unutar svakog od dva dobivena faktora, faktori su imenovani sljedećim nazivima: prvi faktor nazvan je Negativni komentari partnera/ ice, a drugi faktor Pozitivni komentari partnera/ice. Korelacija između dva faktora je niska i negativna, ali značajna te iznosi $r=-, 11(p<, 001)$. Upitnik pruža mogućnost dobivanja rezultata o učestalosti primanja pozitivnih, odnosno negativnih komentara o tjelesnom izgledu. Teorijski raspon rezultata za podljestvicu Negativni komentari partnera/ice kreće se od 16 do 80, a za podljestvicu Pozitivni komentari partnera/ice od 10 do 50. Viši rezultat na ljestvici pozitivnih/negativnih komentara upućuje na veću učestalost primanja partnerovih/ičinih pozitivnih/negativnih komentara o tjelesnom izgledu. Pouzdanost tipa unutarnje konzistencije na našem uzorku za podljestvicu Negativni komentari partnera/ice iznosi $\alpha=, 95$, a za podljestvicu Pozitivni komentari partnera/ice $\alpha=, 84$.

Zanimljiv nalaz je da sudionici čestice "Mislim da bi se trebao/la malo udebljati" i "Izgledaš nekako mršavo" smatraju komplimentima, odnosno navedene čestice se svrstavaju pod drugi faktor koji se odnosi na Pozitivne komentare partnera/ice. Navedene nalaze možemo objasniti idealom mršavosti koji je posljednjih desetljeća izražen među ženskom, ali sve više i muškom populacijom (Arroyo i Harwood, 2012; Mills i Fuller-Tyszkiewicz, 2016; Weller i Dziegielewski, 2005).

Prikupljeni su podaci i o spolu, dobi, trenutačnoj i željenoj tjelesnoj težini i visini i o statusu veze te dužini sadašnje/posljednje veze. Za potrebe istraživanja osmišljene su čestice kojima je ispitana procjena ozbiljnosti sadašnje/posljednje veze te 
procjena važnosti koju partner/ica pridaje tjelesnom izgledu svog/svoje partnera/ ice. Sudionici su odgovarali na skali Likertova tipa (od 1 = uopće se ne slažem do 5 $=\mathrm{u}$ potpunosti se slažem). Čestice su bile prilagođene statusu veze sudionika (npr. "Smatram da sam u ozbiljnoj vezi s trenutačnim partnerom/icom" za one koji su trenutačno u vezi, odnosno "Vezu s prethodnim/om partnerom/icom sam smatrao/ la ozbiljnom" za sudionike koji trenutačno nisu u vezi).

\section{POSTUPAK}

Podaci su prikupljani distribuiranjem poveznice na online upitnik izrađen putem aplikacije Google obrasci na društvenoj mreži Facebook i elektroničkom poštom metodom snježne grude. Na početnoj stranici upitnika navedeno je kratko objašnjenje svrhe istraživanja uz napomenu da je sudjelovanje dobrovoljno i anonimno te o mogućnosti povlačenja iz istraživanja u bilo kojem trenutku. Prije svakog seta pitanja u upitniku nalazile su se detaljne upute, a ukupno vrijeme predviđeno za ispunjavanje bilo je između 10 i 15 minuta.

\section{REZULTATI}

Podaci prikupljeni od 371 sudionika koji su uključeni u daljnju obradu analizirani su pomoću statističkog programa za društvene znanosti IBM SPSS Statistics 25. Prije provedbe analiza u svrhu odgovaranja na istraživačke probleme učinjene su preliminarne analize. U Tablici 1 prikazani su deskriptivni podaci mjernih instrume-

Tablica 1. Deskriptivna statistika istraživačkih varijabli za ukupni uzorak $(n=371)$

\begin{tabular}{lccccccc}
\hline Mjerni instrument/ljestvica & $k$ & $T R$ & $M$ & $S D$ & $K-S$ & $\begin{array}{c}\text { Indeks } \\
\text { asimetričnosti }\end{array}$ & $\begin{array}{c}\text { Indeks } \\
\text { spljoštenosti }\end{array}$ \\
\hline Zadovoljstvo tijelom & 14 & $1-5$ & 3,6 & 0,99 &, $07^{* *}$ &,- 523 &, 082 \\
Važnost slike tijela & 14 & $1-5$ & 3,7 & 0,78 &, $08^{* *}$ &,- 639 & 1,186 \\
\hline $\begin{array}{l}\text { Percipirana kvaliteta romantične } \\
\text { veze }\end{array}$ & 18 & $1-7$ & & &, $14^{* *}$ & $-1,532$ & 2,375 \\
Sudionici koji su u vezi & & & & & & & \\
Sudionici koji nisu u vezi & & & 6,2 & 0,36 & & & \\
\hline
\end{tabular}

Upitnik utjecaja komentara partneralice o tjelesnom izgledu

$\begin{array}{llllllll}\text { Pozitivni komentari partnera/ice } & 10 & 1-5 & 2,8 & 0,78 & , 05^{* *} & -, 068 & -, 526\end{array}$

$\begin{array}{llllllll}\text { Negativni komentari partnera/ice } & 16 & 1-5 & 1,8 & 0,76 & , 18 * * & 1,405 & 1,368\end{array}$

Napomena. $k=$ broj čestica; $T R=$ teorijski raspon rezultata; $M=$ aritmetička sredina; $S D=$ standardna devijacija; $K-S=$ Kolmogorov-Smirnovljeva Z-vrijednost; ${ }^{* *} p<, 001$. 
nata dobiveni u ovom istraživanju. Prikazani su podaci o aritmetičkim sredinama, standardnim devijacijama, teorijskom rasponu rezultata, broju čestica unutar svake ljestvice, Kolmogorov-Smirnovljevu testu normalnosti distribucije te o indeksima asimetričnosti i spljoštenosti. Podaci o aritmetičkim sredinama i standardnim devijacijama prikazani su u svojim relativnim vrijednostima, odnosno vrijednostima za česticu.

Iz Tablice 1 vidljivo je kako se sve raspodjele rezultata statistički značajno razlikuju od normalne i to na način da su sve, osim podljestvice Negativni komentari partnera/ice, koja je negativno asimetrična, pozitivno asimetrične. Ipak, u daljnjim analizama korišteni su parametrijski postupci jer pretpostavljamo da ovakva odstupanja neće bitno utjecati na rezultate statističkih postupaka koji zahtijevaju normalitet distribucija. Naime, standardni postupci, koji zahtijevaju normalitet distribucija, daju neprihvatljive rezultate samo u slučaju kada podaci sugeriraju da su pretpostavke parametrijske statistike narušene u ekstremnom stupnju. U drugim slučajevima, iako distribucije odstupaju od normalnih, ovi postupci daju prihvatljive rezultate (Aron, Coups i Aron, 2006). Također, Petz (1997) navodi kako je uvjet za korištenje parametrijske statistike da distribucije nisu bimodalne ili u obliku U-krivulje. S obzirom na navedeno, primijenjeni su parametrijski testovi.

Za ispitivanje spolnih razlika u zadovoljstvu tijelom, važnosti slike tijela te čestini dobivanja pozitivnih i negativnih komentara o tjelesnom izgledu od partnera/ ice proveden je t-test za velike nezavisne uzorke. Prije provedbe zasebnih t-testova za navedene varijable primijenili smo Levenov test kako bismo provjerili jesu li testirane veličine varijance jednake. Međutim, kod ljestvice Važnost slike tijela i

Tablica 2. Deskriptivni podaci za ženske $(n=277)$ i muške sudionike $(n=94)$, rezultati Levenova testa te značajnosti spolnih razlika za istraživačke varijable

\begin{tabular}{|c|c|c|c|c|c|c|c|}
\hline \multirow{2}{*}{$\begin{array}{l}\text { Mjerni instrument/ } \\
\text { ljestvica }\end{array}$} & \multirow[b]{2}{*}{ Spol } & \multirow[b]{2}{*}{$M u$} & \multirow[b]{2}{*}{$M$} & \multirow[b]{2}{*}{$S D$} & \multirow{2}{*}{$\begin{array}{c}\text { Levenov test } \\
F \\
\end{array}$} & \multicolumn{2}{|c|}{ t-test } \\
\hline & & & & & & $t$ & $d f$ \\
\hline \multirow[t]{2}{*}{ Zadovoljstvo tijelom } & ženski & 50,5 & 50,1 & 9,93 & ,02 & 1,28 & 369 \\
\hline & muški & & 51,6 & 9,74 & & & \\
\hline \multirow[t]{2}{*}{ Važnost slike tijela } & ženski & 51,31 & 51,6 & 8,44 & $12,8^{* *}$ &,- 743 & 128,4 \\
\hline & muški & & 50,6 & 11,53 & & & \\
\hline \multirow{2}{*}{$\begin{array}{l}\text { Negativni komentari } \\
\text { partnera/ice }\end{array}$} & ženski & 28,6 & 26,9 & 12,84 &, 17 & $3,73 * *$ & 369 \\
\hline & muški & & 33,5 & 15,40 & & & \\
\hline \multirow{2}{*}{$\begin{array}{l}\text { Pozitivni komentari } \\
\text { partnera/ice }\end{array}$} & ženski & 28,3 & 28,3 & 7,79 & $8,45^{*}$ &,- 02 & 139,4 \\
\hline & muški & & 28,3 & 8,12 & & & \\
\hline
\end{tabular}

Napomena $. n=$ broj sudionika u poduzorcima; $M u=$ aritmetička sredina cijelog uzorka; $M=$ aritmetička sredina poduzoraka; $S D=$ standardna devijacija; $t=\mathrm{t}$-test; $d f=$ stupnjevi slobode; $F=$ F-omjer; ${ }^{*} p<, 01 ; * * p<, 001$. 
podljestvice Negativni komentari partnera/ice Levenov test pokazao se statistički značajnim, dok se kod ljestvice Zadovoljstvo tijelom i podljestvice Pozitivni komentari partnera/ice nije, zbog čega možemo zaključiti da se varijance međusobno značajno ne razlikuju. Rezultati provedenog Levenova testa prikazani su u Tablici 2.

Rezultati pokazuju kako između žena i muškaraca nema razlike u zadovoljstvu tijelom, u važnosti koju pridaju slici tijela ni u čestini dobivanja pozitivnih komentara o tjelesnom izgledu od partnera/ice. Međutim, muškarci u odnosu na žene češće dobivaju negativne komentare o tjelesnom izgledu od svojih partnera/ica.

Kako bi se ispitao doprinos dobi, željene promjene tjelesne težine, važnosti slike tijela, statusa veze, dužine veze, zadovoljstva vezom, komentara partnera/ice o tjelesnom izgledu te procjene važnosti koju partner/ica pridaje tjelesnom izgledu svog/svoje partnera/ice u objašnjavanju zadovoljstva tijelom, provedene su hijerarhijske regresijske analize. U Prilogu 2 prikazane su interkorelacije prediktorskih varijabli korištenih u hijerarhijskoj regresijskoj analizi predviđanja zadovoljstva tijelom. Vidljivo je kako ispitane prediktorske varijable nisu u međusobnim visokim korelacijama. Statistički značajne korelacije kreću se u rasponu od ,11 do ,51, pri čemu najvišu povezanost pokazuju varijable dužina veze i dob sudionika. U upitniku Percipirana kvaliteta romantične veze spojili smo rezultate sudionika koji jesu $i$ onih koji trenutačno nisu u vezi. Budući da smo varijablu status veze upotrebljavali kao jedan od prediktora, odlučili smo se za spajanje navedenih varijabli, a opravdanje smo pronašli u podjednakoj faktorskoj strukturi, podjednakim korelacijama između faktora i podjednakim pouzdanostima izračunatim na različitim poduzorcima. Također, sudionici su ispunjavali jedan upitnik, odnosno odgovarali na jednake čestice koje su stavljene u sadašnje ili prošlo vrijeme ovisno o statusu veze kako bi im bilo olakšano razumijevanje i odgovaranje.

Budući da su preliminarne analize pokazale kako postoje razlike između žena i muškaraca, odlučili smo napraviti odvojene hijerarhijske regresijske analize predviđanja zadovoljstva tijelom za žene i muškarce kako bi rezultati bili što jasniji, a izvedeni zaključci što točniji. U prvom je koraku hijerarhijskih regresijskih analiza uvedena varijabla dobi, u drugom varijable željene promjene tjelesne težine i važnosti slike tijela, a u trećem varijable statusa veze (u vezi; nisu u vezi), dužine veze, zadovoljstva vezom, pozitivnih i negativnih komentara partnera/ice o tjelesnom izgledu te procjene važnosti koju partner/ica pridaje tjelesnom izgledu svog/svoje partnera/ice.

U Tablici 3 prikazani su rezultati hijerarhijske regresijske analize predviđanja zadovoljstva tijelom na poduzorku žena. Varijabla željena promjena tjelesne težine uvedena u drugom koraku i varijabla pozitivni komentari partnera/ice o tjelesnom izgledu uvedena u trećem koraku varijabli pokazale su se kao značajni prediktori zadovoljstva tijelom. Varijablom željena promjena tjelesne težine objašnjeno je 18\% varijance kriterija, a varijablom pozitivni komentari o tjelesnom izgledu partnera/ ice dodatnih 16\% varijance, čime je objašnjeno ukupno 34\% varijance zadovoljstva tijelom. Žene kod kojih je razlika između trenutačne i željene tjelesne težine manja 
Tablica 3. Rezultati hijerarhijske regresijske analize predviđanja zadovoljstva tijelom na poduzorku žena $(n=277)$

\begin{tabular}{|c|c|c|c|c|}
\hline & & 1. korak & 2. korak & 3. korak \\
\hline & Prediktori & $\beta$ & $\beta$ & $\beta$ \\
\hline 1 & Dob &,- 01 & ,06 &, 05 \\
\hline \multirow[t]{2}{*}{2} & Željena promjena tjelesne težine & &,$- 43 * *$ &,$- 28 * *$ \\
\hline & Važnost slike tijela & &,- 03 &,- 02 \\
\hline \multirow[t]{11}{*}{3} & Status veze & & & ,04 \\
\hline & Dužina veze & & &,- 04 \\
\hline & Zadovoljstvo vezom & & &, 10 \\
\hline & Pozitivni komentari partnera/ice & & &, $34 * *$ \\
\hline & Negativni komentari partnera/ice & & &,- 10 \\
\hline & $\begin{array}{l}\text { Važnost koju partner/ica pridaje tjelesnom izgledu } \\
\text { partnerice }\end{array}$ & & &,- 09 \\
\hline & $R^{2}$ &, 00 &, 18 &, 34 \\
\hline & Korigirani $R^{2}$ &,- 00 &, 17 &, 31 \\
\hline & $\mathrm{F}$ &, 05 & $19,64 * *$ & $15,02 * *$ \\
\hline & $\Delta \mathrm{R}^{2}$ & &, 18 &, 16 \\
\hline & $\Delta \mathrm{F}$ & & $29,43 * *$ & $10,63 * *$ \\
\hline
\end{tabular}

Napomena: $\beta=$ standardizirani regresijski koeficijent; $R^{2}=$ koeficijent determinacije; Korigirani $R^{2}=$ vrijednost koeficijenta determinacije korigirana za broj varijabli u modelu; $F=$ F-omjer; $\Delta \mathrm{R}^{2}=$ promjena vrijednosti koeficijenta determinacije; $\Delta \mathrm{F}=$ promjena vrijednosti $\mathrm{F}$ - omjera; $* * p<, 01$.

i koje dobivaju više pozitivnih komentara o tjelesnom izgledu od svojih partnera/ ica, zadovoljnije su svojim tijelom. Ostale varijable uključene u ovaj pretpostavljeni model nisu se pokazale značajnim prediktorima zadovoljstva tijelom na poduzorku žena.

U Tablici 4 prikazani su rezultati hijerarhijske regresijske analize predviđanja zadovoljstva tijelom na poduzorku muškaraca. Tek je uvođenjem varijable negativni komentari o tjelesnom izgledu partnera/ice u trećem koraku objašnjeno značajnih $20 \%$ varijance kriterija koji se ujedno pokazao i kao jedini značajni (negativni) prediktor u pretpostavljenom modelu predviđanja zadovoljstva tijelom kod muškaraca. Tijelom su zadovoljniji muškarci koji dobivaju manje negativnih komentara od svojih partnera/ica o svom tjelesnom izgledu. 
Tablica 4. Rezultati hijerarhijske regresijske analize predviđanja zadovoljstva tijelom na poduzorku muškaraca $(n=94)$

\begin{tabular}{|c|c|c|c|c|}
\hline & Prediktori & $\begin{array}{c}\text { 1. korak } \\
\beta\end{array}$ & $\begin{array}{c}\text { 2. korak } \\
\beta\end{array}$ & $\begin{array}{c}\text { 3. korak } \\
\beta\end{array}$ \\
\hline 1 & Dob &,- 01 &, 05 &, 14 \\
\hline \multirow[t]{2}{*}{2} & Željena promjena tjelesne težine & &,$- 26^{*}$ &,- 13 \\
\hline & Važnost slike tijela & & 02 &, 11 \\
\hline \multirow[t]{11}{*}{3} & Status veze & & &,- 04 \\
\hline & Dužina veze & & &,- 09 \\
\hline & Zadovoljstvo vezom & & &,- 01 \\
\hline & Pozitivni komentari partnera/ice & & & ,20 \\
\hline & Negativni komentari partnera/ice & & &,$- 34 * *$ \\
\hline & $\begin{array}{l}\text { Važnost koju partner/ica pridaje tjelesnom izgledu } \\
\text { partnera }\end{array}$ & & &,- 07 \\
\hline & $R^{2}$ &, 00 &, 06 & 20 \\
\hline & Korigirani $R^{2}$ &,- 01 & ,03 &, 12 \\
\hline & $F$ & ,02 & 2,06 & $2,39 *$ \\
\hline & $\Delta \mathrm{R}^{2}$ & & 06 &, 14 \\
\hline & $\Delta \mathrm{F}$ & & 3,08 & $2,45^{*}$ \\
\hline
\end{tabular}

Napomena: $\beta=$ standardizirani regresijski koeficijent; $R^{2}=$ koeficijent determinacije; Korigirani $R^{2}=$ vrijednost koeficijenta determinacije korigirana za broj varijabli u modelu; $F=$ F-omjer; $\Delta \mathrm{R}^{2}=$ promjena vrijednosti koeficijenta determinacije; $\Delta \mathrm{F}=$ promjena vrijednosti $\mathrm{F}$ - omjera; $* * p<, 01 ; * p<, 05$.

\section{RASPRAVA}

Cilj ovog istraživanja bio je ispitati spolne razlike u izraženosti zadovoljstva tijelom, važnosti slike tijela i čestini dobivanja pozitivnih i negativnih komentara o tjelesnom izgledu od partnera/ice te provjeriti doprinos nekih bioloških i psiholoških varijabli te varijabli vezanih uz romantičnu vezu u objašnjavanju zadovoljstva tijelom.

$\mathrm{U}$ okviru prvog istraživačkog problema ispitane su spolne razlike u zadovoljstvu tijelom, važnosti slike tijela i čestini dobivanja pozitivnih i negativnih komentara o tjelesnom izgledu od partnera/ice. Dobiveni rezultati pokazuju kako između žena i muškaraca nema razlike u zadovoljstvu tijelom, kao ni u važnosti slike tijela. Drugim riječima, žene i muškarci podjednako su zadovoljni svojim tijelom te u prosjeku pridaju podjednaku važnost svojoj slici tijela. Međutim, iako muškarci i žene podjednako često dobivaju pozitivne komentare o tjelesnom izgledu od svojih partnera/ica, pokazalo se da muškarci češće dobivaju negativne komentare o tjelesnom izgledu u odnosu na žene. Nalazi istraživanja iz ovog područja nisu u potpunosti 
konzistentni. Naime, većina istraživanja pokazuje kako su žene manje zadovoljne svojim tijelom i tjelesnom težinom od muškaraca (Krishen i Worthen, 2011; Murnen, Poinsatte, Huntsman, Goldfarb i Glaser, 2015). Iako je i veliki broj muškaraca nezadovoljan svojim tijelom, pokazalo se da su muškarci zabrinutiji oblikom svoga tijela i njegovom mišićavošću nego tjelesnom težinom (Carleson-Jones i Crawford, 2005; Furnham, Badmin i Sneade, 2002; Milhausen, Buchholz, Opperman i Benson, 2015). Nadalje, žene u ranijoj dobi počinju posvećivati pažnju svom tjelesnom izgledu te su izložene pritiscima okoline koja veći naglasak stavlja na važnost tjelesnog izgleda kod žena nego muškaraca zbog čega određena istraživanja pronalaze da žene posvećuju veću pažnju važnosti slike tijela (Fredrickson i Roberts, 1997; Sanchez i Broccoli, 2008). S druge strane, novija istraživanja pokazuju da muškarci, kao i žene, sve veću pažnju posvećuju slici tijela ili njenim pojedinim aspektima (Ambwani i Strauss, 2007; Goldsmith i Byers, 2016; McCabe i McGreevy, 2010; Murnen i Karazsia, 2017). Stoga, moguće objašnjenje rezultata našeg istraživanja leži u vrsti ideala koje muškarci i žene žele postići. Novija istraživanja pokazuju da kod muškaraca nailazimo na ideal mišićavosti te da se naglasak stavlja na mršavo, ali snažno i mišićavo tijelo. Ako muškarci taj ideal ne ostvaruju, dolazi do nezadovoljstva vlastitim tijelom (Babarović, 2017; Goins i sur., 2012; Murnen i Karazsia, 2017). S druge strane, kod žena je naglašen ideal mršavosti te je cilj koji žene žele postići mršavo tijelo čvrstih mišića (Betz i Ramsey, 2017; Gervais, Vescio i Allen, 2011; Shelton i Liljequist, 2002).

Iako je izloženost nerealističnim modelima povezana s nezadovoljstvom tijelom kod muškaraca i žena (Blond, 2008; Myers i Crowther, 2009), prilikom ispitivanja spolnih razlika u zadovoljstvu tijelom treba imati na umu da kod muškaraca i žena postoji drugačiji odnos između tjelesne težine i zadovoljstva tijelom. Kod žena prevladava linearan odnos, drugim riječima, žene s većom tjelesnom težinom izražavaju veće nezadovoljstvo, dok je kod muškaraca taj odnos zakrivljen, odnosno muškarci s premalom, ali i prekomjernom tjelesnom težinom izražavaju manje zadovoljstvo tijelom. Međutim, muškarci koji žele povećati svoju tjelesnu težinu, ne žele povećati količinu tjelesne masnoće, već žele biti mišićaviji (Babarović, 2017; Murnen i Karazsia, 2017; Shelton i Liljequist, 2002).

Budući da su primijenjeni upitnici sadržavali čestice koje se odnose kako na zadovoljstvo i važnost čvrstoće i veličine mišića, tako i na zadovoljstvo i važnost tjelesne težine, moguće je da smo njime zahvatili pojedine tjelesne aspekte koji dovode do (ne)zadovoljstva i kod muškaraca i kod žena. Zbog čestica koje zahvaćaju i ideal mišićavosti, ali i ideal mršavosti, moguće je da nismo dobili spolne razlike u općem zadovoljstvu tijelom ni u važnosti slike tijela. Kako bismo to provjerili, proveli smo dodatnu analizu, t-test za nezavisne uzorke, prikazanu u Prilogu 3. Rezultati pokazuju da doista postoje razlike između muškaraca i žena na pojedinim česticama, odnosno postoji razlika u zadovoljstvu pojedinim dijelovima tijela. Muškarci su zadovoljniji čvrstoćom mišića, stražnjicom, bedrima i nogama u odnosu na žene. Naime, upravo su stražnjica, bedra i noge dijelovi tijela kojima žene 
posvećuju više pažnje zbog ideala mršavosti usko vezanog uz navedene dijelove tijela zbog čega je moguće da su na tim česticama sudionice dale niže procjene koje upućuju na niže zadovoljstvo. Nadalje, očekivan je i dobiveni nalaz da su ženama tjelesna težina, izgled bokova, stražnjice, bedara, nogu, trbuha i struka važniji nego muškarcima. Muškarci veći naglasak stavljaju na važnost visine, veličine i snage mišića, čvrstoću mišića, izgled ramena i ruku u cjelini. Razmatrajući rezultate iz ovog aspekta možemo zaključiti kako su oni u skladu sa slikom tijela koja se nameće ženama, odnosno muškarcima te pokazuju da primijenjeni upitnik sadrži čestice relevantne i za žene i za muškarce. Nadalje, nerazlikovanje povećanja tjelesne težine i povećanja mišićne mase također može biti razlog koji leži u pozadini dobivenih rezultata ovog istraživanja.

Pitanje utjecaja pozitivnih i negativnih komentara o tjelesnom izgledu partnera/ ice do sada nije detaljno istraživano te su se istraživanja pretežno usmjeravala na komentare o tjelesnoj težini (Carriere i Kluck, 2014; Goldsmith i Byers, 2016). Jedan od razloga malog broja istraživanja jest nedostatak valjanih mjera za istraživanje utjecaja komentara o tjelesnom izgledu upućenih od strane partnera/ice (Carriere i Kluck, 2014). Ipak, novija istraživanja uglavnom pokazuju da između muškaraca i žena ne postoji razlika u čestini dobivanja pozitivnih i negativnih komentara o tjelesnom izgledu te da osobe češće primaju pozitivne od negativnih komentara o tjelesnom izgledu, što nije u skladu s prijašnjim nalazima koji pokazuju da pojedinci češće dobivaju negativne komentare, posebice u vezi s tjelesnom težinom (Goldsmith i Byers, 2016). McCabe i McGreevy (2010) u svom istraživanju pronalaze da muškarci uglavnom dobivaju pozitivne komentare o tjelesnom izgledu, a ako su dobili negativne komentare, oni su uglavnom bili motivirani zabrinutošću za zdravljem, a ne izgledom. Moguće je da i u našem istraživanju negativni komentari nisu bili upućeni zbog nezadovoljstva tjelesnim izgledom, nego zbog zdravstvenih razloga, no budući da nismo ispitali kontekst i razloge u podlozi određenog komentara, ne možemo znati zbog čega se na našem uzorku pokazalo da muškarci češće dobivaju negativne komentare od svojih partnera/ica o svom tjelesnom izgledu.

U okviru drugog istraživačkog problema htjeli smo ispitati doprinos nekih bioloških (spol, dob) i psiholoških varijabli (željena promjena tjelesne težine, važnost slike tijela) te varijabli vezanih uz romantičnu vezu (status veze, dužina veze, zadovoljstvo vezom, komentari partnera/ice o tjelesnom izgledu, procjena važnosti koju partner/ica pridaje tjelesnom izgledu svog/svoje partnera/ice) u objašnjavanju zadovoljstva tijelom. Preliminarnim analizama (korelacijama, testiranjem značajnosti, hijerarhijskom regresijskom analizom na cijelom uzorku) utvrđeno je kako se jasniji rezultati dobivaju ako se provedu zasebne analize na poduzorku žena i poduzorku muškaraca. Pretpostavljeni model predviđanja zadovoljstva tijelom samo je djelomično potvrđen. Hijerarhijskom regresijskom analizom na poduzorku žena utvrđeno je kako su manja željena promjena tjelesne težine i pozitivni komentari o tjelesnom izgledu značajni pozitivni prediktori zadovoljstva tijelom, dok se na 
poduzorku muškaraca kao jedini značajni negativni prediktor zadovoljstva tijelom pokazala varijabla negativni komentari o tjelesnom izgledu.

Iako smo očekivali kako će dob značajno pridonijeti objašnjenju varijance kriterija zadovoljstva tijelom, ona se nije pokazala značajnim prediktorom. Rezultati longitudinalnog desetogodišnjeg istraživanja pokazuju kako i žene i muškarci postaju nezadovoljniji tjelesnim izgledom u razdoblju od 10 godina te da je taj trend praćen povećanjem njihova ITM-a tijekom tog vremenskog razdoblja. Međutim, dio istraživača pronalazi kako se nezadovoljstvo tijelom povećava od adolescencije do odraslosti u nastajanju jer s dobi postajemo svjesniji sociokulturnih utjecaja i ideala koji nam se nameću (Bucchianeri i sur., 2013; McCabe i Ricciardelli, 2004), drugi ne pronalaze razlike u zadovoljstvu tjelesnim izgledom ovisno o dobi (von Soest i Wichstrom, 2009), dok neka istraživanja pronalaze da se nezadovoljstvo tijelom smanjuje tijekom mlađe odrasle dobi te postaje relativno stabilno u 20-ima (Cooley i Toray, 2001). Mogući razlog nalaza ovog istraživanja jest što su uzorak pretežno činili studenti, odnosno mlade osobe u razdoblju odraslosti u nastajanju uz nešto manji broj sudionika drugih dobnih skupina, što je svakako nedostatak ovog istraživanja.

Pitanje tjelesne težine i zadovoljstva tijelom jasno je do sada empirijski potvrđivano. Tjelesna težina značajno predviđa zadovoljstvo tijelom. Drugim riječima, pojedinci koji imaju viši ITM od prosječnog, odnosno imaju prekomjernu tjelesnu težinu, iskazuju niže zadovoljstvo tijelom te su pod većim pritiskom da dosegnu postavljene ideale, što posebice vrijedi za žene (Blodgett Salafia i Benson, 2013; Luciano, 2007; Markey i Markey, 2011; McCabe i McGreevy, 2010; Stice, 2002). Također, pojedinci kojima se trenutačna i željena tjelesna težina značajno razlikuju, manje su zadovoljni vlastitim tijelom: veći raskorak između trenutačne i željene tjelesne težine dovodi do većeg nezadovoljstva tijelom (Weaver i Byers, 2006). Drugim riječima, pojedinci kojima su trenutačna i željena tjelesna težina sličnih vrijednosti (manja diskrepanca) i oni koji imaju manju tjelesnu težinu zadovoljniji su tijelom (Cash, Jakatdar i Williams, 2004), što je u skladu s dijelom rezulatata našeg istraživanja na poduzorku žena. Razlog neznačajnog doprinosa željene promjene tjelesne težine u objašnjavanju nezadovoljstva tijelom muškaraca možda leži u nalazu dosadašnjih istraživanja kako muškarci s premalom, ali i s prekomjernom tjelesnom težinom izražavaju manje zadovoljstvo tijelom. Kod žena je, međutim, taj odnos linearan, odnosno žene s većom tjelesnom težinom izražavaju veće nezadovoljstvo tijelom. Uz navedeno, potrebno je napomenuti kako je kod studentske populacije zamijećena velika fluktuacija u tjelesnoj težini (Viner i Cole, 2006).

Ograničen je broj istraživanja koja se bave pitanjem zadovoljstva tijelom i važnosti slike tijela jer se često zanemaruje uloga važnosti koju osoba pridaje svom tjelesnom izgledu. Postojeća istraživanja pokazuju da postoji umjerena povezanost zadovoljstva tijelom i važnosti slike tijela koja upućuje na to da su konstrukti povezani, ali ne i redundantni (Rieder i Ruderman, 2001.). Važnost slike tijela dovodi do nezadovoljstva tijelom kada pojedinci osjećaju da ne dostižu nametnute ideale 
(McCabe i McGreevy, 2010). Budući da naši sudionici daju prosječnu vrijednost važnosti slike tijela te da nismo ispitali njihove stavove o nametnutim idealima, moguće je da njihov tjelesni izgled ne utječe na njihov osjećaj vlastite vrijednosti te da ne dovodi do nezadovoljstva tijelom.

Određena istraživanja pronalaze da status veze, odnosno bivanje ili nebivanje u njoj imaju određeni učinak na zadovoljstvo tijelom (Davison i McCabe, 2005). Naime, prema nekim nalazima, osobe, ponajprije žene koje nisu u vezi, manje su zadovoljne tijelom, dok su osobe koje su u vezi, njime zadovoljnije (Blodgett Salafia i Benson, 2013; Forbes i sur., 2006; Gondoli i sur., 2011; Lin i Kulik, 2002). Neka pak istraživanja ne pronalaze povezanost statusa veze i zadovoljstva tijelom (Blodgett Salafia i Benson, 2013; Paxton i sur., 2005). Uzimajući u obzir da se na našem uzorku zadovoljstvo tijelom pokazalo prosječnim do visokim, moguće je da status veze ne pridonosi zadovoljstvu njime.

Nadalje, zbog nalaza da žene osjećaju veći pritisak za održavanjem privlačnog tjelesnog izgleda, čak i nakon što nađu partnera, pretpostavili smo da je dužina veze negativno povezana sa zadovoljstvom tijelom. Međutim, istraživanja daju nekonzistentne nalaze. Dok neka pokazuju da žene koje su duže u vezi izjavljuju kako smatraju da je njihov partner manje zadovoljan njihovim tijelom u odnosu na početak veze, što kod njih uzrokuje nezadovoljstvo tijelom (Goins i sur., 2012; Markey i Markey, 2006), druga pokazuju da su osobe koje su duže u romantičnoj vezi zadovoljnije vlastitim tijelom, odnosno da dužina veze smanjuje opterećenost vlastitim izgledom i umanjuje utjecaj nerealnih ideala o tjelesnom izgledu (Tom i sur., 2005). Iako neka istraživanja pokazuju da partnerova/ičina percepcija partnerova/ ičina tjelesnog izgleda može utjecati na sliku tijela i zadovoljstvo tijelom, navedena veza nije detaljnije istraživana (Blodgett Salafia i Benson, 2013; Goins i sur., 2012; Weaver i Byers, 2006). Budući da smo procjenu važnosti koju partner/ica pridaje tjelesnom izgledu svog/svoje partnera/ice mjerili samo jednom česticom, čime nisu zahvaćeni različiti aspekti tjelesnog izgleda, ova mjera predstavlja grubu procjenu zbog čega je moguće da se u našem pretpostavljenom modelu ova varijabla nije pokazala značajnim prediktorom zadovoljstva tijelom kako žena, tako i muškaraca.

Budući da su romantični partneri/ice snažan izvor informacija o tjelesnom izgledu, pretpostavili smo da će njihovi komentari o tjelesnom izgledu utjecati na zadovoljstvo tijelom. Dosadašnja istraživanja pokazuju da i pozitivni i negativni komentari utječu na sliku tijela i zadovoljstvo tijelom osobe (Carriere i Kluck, 2014; Collins i Laursen, 2000). Pozitivni komentari o tjelesnom izgledu dovode do većeg samopouzdanja i prihvaćanja tijela te većeg zadovoljstva njime, dok negativni komentari, osobito oni vezani uz tjelesnu težinu, mogu dovesti do nezadovoljstva tijelom (Blodgett i sur., 2013; Evans i Stukas, 2007; Goldsmith i Byers, 2016; Weller i Dziegielewski, 2005). Rezultati našeg istraživanja pokazuju kako veća učestalost pozitivnih komentara partnera/ica predviđa veće zadovoljstvo tijelom kod žena, dok veća učestalost negativnih komentara o tjelesnom izgledu predviđa niže zadovoljstvo tijelom kod muškaraca. Drugim riječima, manjak pozitivnih komentara 
partnera/ice o tjelesnom izgledu prediktivan je za veće nezadovoljstvo tijelom žena, dok izostanak negativnih komentara o tjelesnom izgledu predviđa veće zadovoljstvo tijelom muškaraca.

\section{Metodološki nedostaci i preporuke za buduća istraživanja}

Ovo istraživanje ima nekoliko metodoloških nedostataka koji su potencijalno utjecali na rezultate istraživanja i na valjanost dobivenih rezultata. Prvi nedostatak veže se uz sam uzorak koji čine pretežno studentice koje su samostalno i dobrovoljno odlučile sudjelovati u istraživanju koje je bilo provedeno online. Upitniku su najvjerojatnije pristupili sudionici koji su zainteresirani za temu, što uzorak čini samoselekcioniranim, a zbog čega je otežana generalizacija dobivenih rezultata. Također, istraživanje je korelacijsko zbog čega nije moguće donositi uzročno-posljedične zaključke. Nadalje, u istraživanju je korišteno 10 prediktora, a pokazuje se da je višestruka korelacija pristran pokazatelj jer se njezina očekivana vrijednost povećava s brojem korištenih prediktora (Milas, 2005). Primjedba ovom istraživanju može biti i korištenje procjena za prošlu/prethodnu vezu vezana uz prošla ponašanja i doživljena iskustva u njoj.

Ovo istraživanje pokazuje da uključivanjem čestica koje se odnose na tjelesnu težinu i na mišićnu masu ne pronalazimo razlike u zadovoljstvu tijelom između muškaraca i žena. Istraživanja zadovoljstva tijelom velikim su dijelom provođena na ženama te su bila usmjerena na teme koje su važne ženama, poput održavanja vitke linije ili gubitka težine, zbog čega postoji mogućnost da nisu dala potpunu sliku zadovoljstva tijelom kod muškaraca, odnosno da je to dovelo do podcjenjivanja problema s kojima se muškarci u ovom području susreću. Prilikom razmatranja spolnih razlika, svakako bi trebalo uključiti i različite dobne skupine jer su neka istraživanja pronašla da postoje određene razlike u zadovoljstvu tijelom između muškaraca i žena ovisno o dobi (Murnen i Karazsia, 2017). U budućim bi istraživanjima bilo zanimljivo uzeti u obzir i partnerov/ičin ITM budući da razlike u ITM-u između partnera mogu dovesti do manjeg zadovoljstva tijelom (Markey i Markey, 2011). Također, ovim istraživanjem nije ispitivana seksualna orijentacija sudionika i sudionica, što bi u budućim istraživanjima bilo poželjno uzeti u obzir kao mogući korelat ispitivane problematike.

\section{ZAKLJUČAK}

Rezultati ovog istraživanja pokazuju kako između žena i muškaraca nema razlika u zadovoljstvu tijelom, važnosti slike tijela ni razlike u čestini dobivanja pozitivnih komentara o tjelesnom izgledu od partnera/ice. Međutim, pokazalo se da muškarci češće dobivaju negativne komentare o tjelesnom izgledu u odnosu na žene. Hijerarhijskim regresijskim analizama utvrđeno je kako su za žene željena 
promjena tjelesne težine i pozitivni komentari o tjelesnom izgledu od strane partnera/ice značajni prediktori zadovoljstva tijelom, dok je kod muškaraca varijabla negativni komentari o tjelesnom izgledu partnera/ice značajan negativni prediktor njihova zadovoljstva tijelom.

\section{LITERATURA}

Ambwani, S. i Strauss, J. (2007). Love Thyself Before Loving Others? A Qualitative and Quantitative Analysis of Gender Differences in Body Image and Romantic Love. Sex Roles, 56, 13-21.

Aron, A., Coups, E. J. i Aron, E. N. (2006). Statistics for psychology. Upper Saddle River: Pearson Education, Inc.

Arroyo, A. i Harwood, J. (2012). Exploring the Causes and Consequences of Engaging in Fat Talk. Journal of Applied Communication Research, 40(2), 167-187.

Babarović, T. (2017). Povezanost indeksa tjelesne mase i zadovoljstva tijelom kod mlađih odraslih muškaraca. Journal of Applied Health Sciences, 3(1), 37-44.

Banfield, S. S., McCabe i M. P. (2002). An evaluation of the construct of body image. Adolescence, 37, 373-384.

Betz, D. E. i Ramsey, L. R. (2017). Should women be "All About That Bass?": Diverse body-ideal messages and women's body image. Body Image, 22, 18-31.

Blodgett Salafia, E. H. i Benson, K. E. (2013). Differences in Emerging-Adult Women's Body Image and Sexuality Outcomes According to BMI and Dating Status. International Journal of Sexual Health, 25, 225-239.

Blond, A. (2008). Impacts of exposure to images of ideal bodies on male body dissatisfaction: A review. Body image, 5(3), 244-250.

Bond, M. J., i McDowell, A. J. (2001). An adolescent conception of body image and weight loss behaviours. Journal of Applied Health Behaviour, 3(2), 8-15.

Boyes, A. D. i Latner, J. D. (2009). Weight Stigma in Existing Romantic Relationships. Journal of Sex \& Marital Therapy, 35(4), 282-293.

Brown, J. N., Stukas, A. A. i Evans, L. (2013). Appearance feedback in intimate relationships: The role of self-verification and self-enhancement. Body Image, 10, 131-134.

Bucchianeri, M. M., Arikian, A. J., Hannan, P. J., Eisenberg, M. E. i Neumark-Sztainer, D. (2013). Body dissatisfaction from adolescence to young adulthood: Findings from a 10year longitudinal study. Body Image, 10, 1-7.

Burke, T. J., Randall, A. K., Corkery, S. A., Young, V. J. i Butler, E. A. (2012). "You're going to eat that?" Relationship processes and conflict among mixed-weight couples. Journal of Social and Personal Relationships, 29(8), 1109-1130.

Carleson-Jones, D. C. i Crawford, J. K. (2005). Adolescent Boys and Body Image: Weight and Muscularity Concerns as Dual Pathways to Body Dissatisfaction. Journal of Youth and Adolescence, 34, 629-636.

Carriere, L. J. i Kluck, A. S. (2014). Appearance commentary from romantic partners: Evaluation of an adapted measure. Body Image, 11, 137-145. 
Cash, T. F., Jakatdar, T. A. i Williams, E. F. (2004). The Body Image Quality of Life Inventory: Further validation with college men and women. Body Image, 1(3), 279-287.

Cash, T. F., Morrow, J. A., Hrabosky, J. I. i Perry, A. A. (2004). How has body image changed? A cross-sectional investigation of college women and men from 1938 to 2001. Journal of Consulting and Clinical Psychology, 72, 1081-1089.

Cash, T. F., Thériault, J. i Annis, N. M. (2004). Body image in an interpersonal context: Adult attachment, fear of intimacy, and social anxiety. Journal of Social and Clinical Psychology, 23, 89-103.

Collins, W. A. i Laursen, B. (2000). Adolescent relationships: The art of fugue. U C. Hendrick, S. S. Hendrick (Ur.), Close relationships, 59-69. Sage Publications, Inc.

Compian, L., Gowen, L. K. i Hayward, C. (2004). Peripubertal girls' romantic and platonic involvement with boys: Associations with body image and depression symptoms. Journal of Research on Adolescence, 14, 23-47.

Cooley, E. i Toray, T. (2001). Disordered eating in college freshman women: A prospective study. Journal of American College Health, 49(5), 229-235.

Dalley, S. E., Pollet, T. V. i Vidal, J. (2013). Body size and body esteem in women: The mediating role of possible self expectancy. Body Image, 10, 411- 414.

Davison, T. E. i McCabe, M. P. (2005). Relationships between men's and women's body image and their psychological, social, and sexual functioning. Sex Roles, 52(7-8), 463475.

Erceg Jugović, I. (2011). Nezadovoljstvo tijelom u adolescenciji. Klinička psihologija, 4(12), 41-58.

Erceg Jugović, I. (2015). Čimbenici nezadovoljstva tijelom u adolescenciji. Neobjavljeni doktorski rad. Zagreb: Odsjek za psihologiju Filozofskog fakulteta u Zagrebu.

Evans, L. i Stukas, A. A. (2007). Self-Verification by Women and Responses of their Partners Around Issues of Appearance and Weight: “Do I Look Fat in this?” Journal of Social and Clinical Psychology, 26(10), 1163-1188.

Fletcher, G. J. O., Simpson, J. A. i Thomas, G. (2000). The Measurement of Perceived Relationship Quality Components: A Confirmatory Factor Analytic Approach. Personality and Social Psychology Bulletin, 26(3), 340-354.

Forbes, G. B., Jobe, R. L. i Richardson, R. M. (2006). Associations Between Having a Boyfriend and the Body Satisfaction and Self-Esteem of College Women: An Extension of the Lin and Kulik Hypothesis. The Journal of Social Psychology, 146(3), 381-384.

Fredrickson, B. L. i Roberts, T. A. (1997). Objectification theory: Toward understanding women's lived experiences and mental health risks. Psychology of Women Quarterly, 21(2), 173-206.

Furnham, A., Badmin, N. i Sneade, I. (2002). Body image dissatisfaction: Gender differences in eating attitudes, self-esteem, and reasons for exercise. The Journal of psychology, 136(6), 581-596.

Gardner, R. M. (2002). Body image assessment in children. U T. F. Cash, T. Pruzinsky (Ur.), Body Image: A Handbook of Theory, Research, and Clinical Practice, 127-134. New York: The Guilford Press. 
Gardner, R. M., Friedman, B. N., Stark, K. i Jackson, N. A. (1999). Body size estimation in children six through fourteen: A longitudinal study. Perceptual and Motor Skills, 88, 541-555.

Gervais, S. J., Vescio, T. K. i Allen, J. (2011). When What You See Is What You Get: The Consequences of the Objectifying Gaze for Women and Men. Psychology of Women Quarterly, 35(1), 5-17.

Goins, L. B., Markey, C. N. i Gillen, M. M. (2012). Understanding Men's Body Image in the Context of Their Romantic Relationships. American Journal of Men's Health, 6(3), 240-248.

Goldsmith, K. M. i Byers, E. S. (2016). Perceived impact of body feedback from romantic partnerson young adults' body image and sexual well-being. Body Image, 17, 161-170.

Gondoli, D. M., Corning, A. F., Blodgett Salafia, E. H., Bucchianeri, M. M. i Fitzsimmons, E. E. (2011). Heterosocial involvement, peer pressure for thinness, and body dissatisfaction among young adolescent girls. Body Image, 8(2), 143-148.

Herbozo, S. i Thompson, J. K. (2006). Appearance-related commentary, body image, and self-esteem: Does the distress associated with the commentary matter?. Body image, $3(3), 255-262$.

Juarez, L. i Pritchard, M. (2012). Body Dissatisfaction: Commitment, Support and Trust in Romantic Relationships. Journal of Human Behavior in the Social Environment, 22, 188-200.

Krishen, A. S. i Worthen, D. (2011). Body image dissatisfaction and self-esteem: A consumer-centric exploration and a proposed research agenda. Journal of Consumer Satisfaction, Dissatisfaction and Complaining Behavior, 24, 90-106.

Lamer, S. A., Reeves, S. L. i Weisbuch, M. (2015). The nonverbal environment of selfesteem: Interactive effects of facial-expression and eye-gaze on perceivers' self-evaluations. Journal of Experimental Social Psychology, 56, 130-138.

Lin, L. F. i Kulik, J. A. (2002). Social comparison and women's body satisfaction. Basic and Applied Social Psychology,24(2), 115-123.

Luciano, L. (2007). Muscularity and masculinity in the United States: A historical overview. In: Thompson, J. K. and Cafri, G., Eds., The Muscular Ideal, American Psychological Association, Washington, D.C., 41-66.

Markey, C. N. i Markey, P. M. (2006). Romantic relationships and body satisfaction among young women. Journal of Youth and Adolescence, 35, 256-264.

Markey, C. N., i Markey, P. M. (2011). Romantic partners, weight status, and weight concerns: An examination of the actor-partner interdependence model. Journal of Health Psychology, 16(2), 217-225.

Markey, C. N., Markey, P. M. i Birch, L. L. (2004). Understanding women's body satisfaction: The role of husbands. Sex Roles, 51(3-4), 209-216.

McCabe, M. P. i McGreevy, S. (2010). The role of partners in shaping the body image and body change strategies of adult men - Partners and male body image. Health, 2(9), 1002-1009.

McCabe, M. P. i Ricciardelli, L. A. (2004). Body image dissatisfaction among males across the lifespan: A review of past literature. Journal of Psychosomatic Research, 56, 675685. 
Meltzer, A. L., McNulty, J. K., Novak, S. A., Butler, E. A. i Karney, B. R. (2011). Marriages Are More Satisfying When Wives Are Thinner Than Their Husbands. Social Psychological and Personality Science, 2(4), 416-424.

Milas, G. (2005). Istraživačke metode u psihologiji i drugim društvenim znanostima. Jastrebarsko: Naklada Slap.

Milhausen, R. R., Buchholz, A. C., Opperman, E. A. i Benson, L. E. (2015). Relationships Between Body Image, Body Composition, Sexual Functioning, and Sexual Satisfaction Among Heterosexual Young Adults. Archives of Sexual Behavior, 44(6), 1621-1633.

Mills, J. i Fuller-Tyszkiewicz, M. (2016). Fat talk and its relationship with body image disturbance. Body Image, 18, 61-64.

Murnen, S. K. i Karazsia, B. T. (2017). A review of research on men's body image and drive for muscularity. In R. F. Levant i Y. J. Wong (Eds.), The psychology of men and masculinities, 229-257.

Murnen, S. K., Poinsatte, K., Huntsman, K., Goldfarb, J. i Glaser, D. (2015). Body ideals for heterosexual romantic partners: Gender and sociocultural influences. Body Image, $12,22-31$.

Murray, S. L., Holmes, J. G. i Griffin, D. W. (1996). The self-fulfilling nature of positive illusions in romantic relationships: Love is not blind but prescient. Journal of Personality and Social Psychology, 71, 1155-1180.

Myers, T. A. i Crowther, J. H. (2009). Social comparison as a predictor of body dissatisfaction: A meta-analytic review. Journal of Abnormal Psychology, 118(4), 683.

Paxton, S. J., Norris, M., Wertheim, E. H., Durkin, S. J. i Anderson, J. (2005). Body dissatisfaction, dating, and importance of thinness to attractiveness in adolescent girls. Sex Roles, 53, 663-675.

Petz, B. (1997). Osnovne statističke metode za nematematičare. Jastrebarsko: Naklada Slap.

Pole, M., Crowther, J. H. i Schell, J. (2004). Body dissatisfaction in married women: The role of spousal influence and marital communication patterns. Body Image, 1(3), $267-$ 278.

Ricciardelli, L. A. i McCabe, M. P. (2002). Psychometric evaluation of the Body ChangeInventory: An assessment instrument for adolescent boys and girls. Eating Behaviors, $2,1-15$.

Rieder, S. i Ruderman, A. (2001). Cognitive Factors Associated With Binge and Purge Eating Behaviors: The Interaction of Body Dissatisfaction and Body Image Importance. Cognitive Therapy and Research, 25(6), 801-812.

Sanchez, D. T. i Broccoli, T. L. (2008). The Romance of Self-objectification: Does Priming Romantic Relationships Induce States of Self-objectification Among Women? Sex Roles, 59, 545-554.

Sheets, V. i Ajmere, K. (2005). Are romantic partners a source of college students' weight concern? Eating Behaviors, 6, 1-9.

Shelton, S. i Liljequist, L. (2002). Characteristics and behaviors associated with body image in male domestic violence offenders. Eating Behaviors, 3, 217-227.

Stice, E. (2002). Risk and maintenance factors for eating pathology: A metaanalytic review. Psychological Bulletin, 128, 825-848. 
Tager, D., Good, G. i Morrison, J. B. (2006). Our bodies, ourselves revisited: Male body image and psychological wellbeing. International Journal of Men's Heath, 5, 228-237.

Thompson, J. K., Heinberg, L. J., Altabe, M., i Tantleff-Dunn, S. (1999). Exacting beauty: Theory, assessment, and treatment of body image disturbance. American Psychological Association.

Tom, G., Chen, A., Liao, H. i Shao, J. (2005) Body image, relationships and time. The Journal of Psychology, 139(5), 458-468.

van den Brink, F., Smeets, M. A. M., Hessen, D. J. i Woertman, L. (2016). Positive Body Image and Sexual Functioning in Dutch Female University Students: The Role of Adult Romantic Attachment. Archives of Sexual Behavior, 45, 1217-1226.

von Soest, T. i Wichstrøm, L. (2009). Gender differences in the development of dieting from adolescence to early adulthood: A longitudinal study. Journal of Research on Adolescence, 19(3), 509-529.

Viner, R. M. i Cole, T. J. (2006). Who changes body mass between adolescence and adulthood? Factors predicting change in BMI between 16 year and 30 years in the 1970 British Birth Cohort. International Journal of Obesity, 30(9), 1368-1374.

Weaver, A. D. i Byers E. S. (2006). The Relationships Among Body Image, Body Mass Index, Exercise, and Sexual Functioning in Heterosexual Women. Psychology of Women Quarterly, 30, 333-339.

Weller, J. E. i Dziegielewski, S. F. (2005).The Relationship Between Romantic Partner Support Styles and Body Image Disturbance. Journal of Human Behavior in the Social Environment, 10(2), 71-92.

World Health Organization (2018). Body mass index - BMI. http://www.euro.who.int/en/ health-topics/disease-prevention/nutrition/a-healthy-lifestyle/body-mass-index-bmi

\title{
THE RELATIONSHIP BETWEEN BODY SATISFACTION, ROMANTIC RELATIONSHIP SATISFACTION AND PARTNER'S FEEDBACK ABOUT APPEARANCE
}

\begin{abstract}
The aim of this research was to test gender differences in body satisfaction, body image importance, frequency of partner's positive and negative feedback on physical appearance, as well as to determine the possibility of predicting body satisfaction based on some psychological variables and variables related to romantic relationship. The sample consisted of 371 participants ( $74.7 \%$ females), age range from 18 to 54 years $(M=24.7 ; S D=5.07)$. The questionnaires included measures of body satisfaction, body image importance, romantic relationship satisfaction and positive and negative feedback on physical appearance from romantic partner. The results have partially confirmed the hypotheses, showing that there are no gender differences in body satisfaction, body image importance and in frequency of received partner's positive feedback on physical appearance. However, men get more negative feedback on
\end{abstract}


their physical appearance from their partners than do women. Hierarchical regression analysis confirmed that for women, smaller desired weight gain/loss and partners' positive feedback on physical appearance are positive predictors of body satisfaction while for men partners' negative feedback on their physical appearance is a negative predictor of body satisfaction.

Key words: body satisfaction, body image importance, romantic relationship satisfaction, partner's feedback on physical appearance, body weight.

Primljeno: 18. 09. 2019. 
Prilog 1. Rezultati faktorske analize čestica Upitnik utjecaja komentara partnera/ice o tjelesnom izgledu nakon provedene analize glavnih komponenata s oblimin rotacijom $(N=371)$

\begin{tabular}{|c|c|c|c|c|}
\hline \multirow{2}{*}{$\begin{array}{l}\text { Broj } \\
\text { čestice }\end{array}$} & \multirow[b]{2}{*}{ Sadržaj čestice } & \multicolumn{2}{|c|}{ Faktorska opterećenja } & \multirow[b]{2}{*}{$\mathrm{h}^{2}$} \\
\hline & & $\mathrm{F} 1$ & F2 & \\
\hline 12. & Jesi li razmišljao/la o odlasku na dijetu? & 849 & & ,721 \\
\hline 24. & Trebao/la bi povećati svoje mišiće. &, 815 & & 664 \\
\hline 14. & Jesi li siguran/na da želiš jesti tako masnu hranu? & ,808 & & 653 \\
\hline 25. & Trbuh ti se malo povećao. & ,803 & & ,645 \\
\hline 10. & Trebao/la bi početi vježbati kako bi smršavio/la. & ,799 & & ,638 \\
\hline 15. & Jesi li se udebljao/la? & ,796 & & ,634 \\
\hline 23. & Mislim da bi mogao/la malo češće vježbati. & ,779 & & 607 \\
\hline 13. & U toj odjeći izgledaš debelo. & ,759 & &, 576 \\
\hline 18. & Što misliš o tome da se upišeš u teretanu? & ,756 & &, 571 \\
\hline 2. & Trebao/la bi pripaziti što jedeš. & ,752 & & ,565 \\
\hline 19. & Trebao/la bi učvrstiti mišiće. & ,746 & & ,556 \\
\hline 7. & Ne misliš li da si već dovoljno pojeo/la? &, 737 & &, 543 \\
\hline 9. & Ne bi trebao/la jesti tako kasno navečer. & ,706 & & ,498 \\
\hline 5. & Udebljao/la si se. & ,699 & & ,489 \\
\hline 26. & Loše izgledaš. & ,670 & & ,449 \\
\hline 22. & Čini mi se da baš nisi u kondiciji. & 651 & & ,424 \\
\hline 21. & Jako si lijepo građen/a. & & ,779 & ,607 \\
\hline 16. & Imaš dobro tijelo. & & ,749 & ,561 \\
\hline 4. & $\begin{array}{l}\text { Vjerujem da drugi mladići/ druge djevojke žele imati } \\
\text { tijelo poput tvojeg. }\end{array}$ & & ,730 & ,533 \\
\hline 6. & U dobroj si formi. & & ,711 & ,505 \\
\hline 20. & Imaš dobre mišiće. & & ,681 & ,464 \\
\hline 11. & Imaš dobre trbušnjake. & & ,645 & ,416 \\
\hline 1. & Ta odjeća naglašava tvoje lijepo tijelo. & & ,643 & ,413 \\
\hline 3. & Zgodan/na si. & & 621 & ,386 \\
\hline 16. & Mislim da bi se trebao/la malo udebljati. & & ,384 &, 147 \\
\hline 8. & Izgledaš nekako mršavo. & & ,334 &, 111 \\
\hline \multicolumn{2}{|c|}{ Eigen vrijednost } & 9,66 & 4,06 & \\
\hline \multicolumn{2}{|c|}{ Postotak objašnjene varijance } & 37,17 & 15,63 & \\
\hline
\end{tabular}




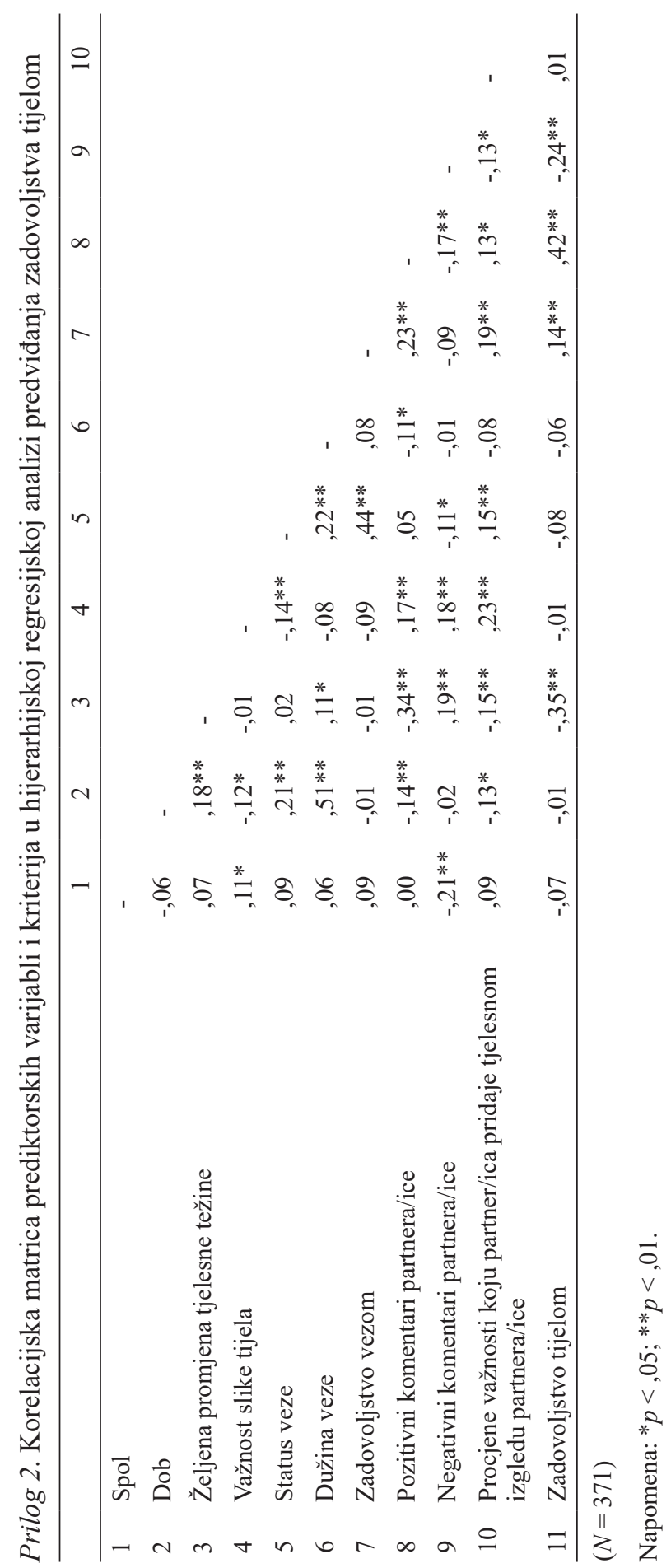


Prilog 3. Deskriptivni podaci za ženske $(n=277)$ i muške sudionike $(n=94)$ te značajnosti spolnih razlika na razini pojedinih čestica unutar ljestvica Zadovoljstvo tijelom i

Važnost slike tijela

\begin{tabular}{|c|c|c|c|c|c|c|}
\hline \multirow{2}{*}{$\begin{array}{l}\text { Broj } \\
\text { čestice }\end{array}$} & \multirow[b]{2}{*}{ Sadržaj čestice } & \multirow[b]{2}{*}{ Rod } & \multirow[b]{2}{*}{$M$} & \multirow[b]{2}{*}{$S D$} & \multicolumn{2}{|c|}{ t-test } \\
\hline & & & & & $t$ & $d f$ \\
\hline \multirow{2}{*}{4.} & \multirow{2}{*}{ zadovoljstvo čvrstoćom mišića } & muški & 3,52 & ,94 & \multirow{2}{*}{$3,36^{* *}$} & \multirow{2}{*}{369} \\
\hline & & ženski & 3,11 & 1,06 & & \\
\hline \multirow{2}{*}{7.} & \multirow{2}{*}{ zadovoljstvo stražnjicom } & muški & 3,89 & ,93 & \multirow{2}{*}{$2,32 *$} & \multirow{2}{*}{369} \\
\hline & & ženski & 3,61 & 1,07 & & \\
\hline \multirow{2}{*}{8.} & \multirow{2}{*}{ zadovoljstvo bedrima } & muški & 3,89 & ,94 & \multirow{2}{*}{$4,11 * *$} & \multirow{2}{*}{369} \\
\hline & & ženski & 3,36 & 1,14 & & \\
\hline \multirow{2}{*}{9.} & \multirow{2}{*}{ zadovoljstvo nogama } & muški & 3,90 & ,92 & \multirow{2}{*}{$3,11^{*}$} & \multirow{2}{*}{369} \\
\hline & & ženski & 3,49 & 1,16 & & \\
\hline \multirow{2}{*}{1.} & \multirow{2}{*}{ važnost tjelesne težine } & muški & 3,67 & ,94 & \multirow{2}{*}{$-3,33 * *$} & \multirow{2}{*}{369} \\
\hline & & ženski & 3,99 &, 75 & & \\
\hline \multirow{2}{*}{2.} & \multirow{2}{*}{ važnost tjelesne visine } & muški & 3,60 & ,97 & \multirow{2}{*}{$3,99 * *$} & 360 \\
\hline & & ženski & 3,12 & 1,01 & & 309 \\
\hline 1 & Važnost yeličine i snoge mišsí́ & muški & 3,77 & ,90 & $100 * *$ & 360 \\
\hline 4. & 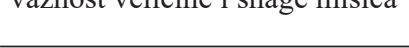 & ženski & 3,20 & ,99 & 4,90: & 309 \\
\hline 5 & 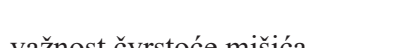 & muški & 3,80 & ,95 & $254 *$ & 360 \\
\hline 3 . & Vazhost c vistoce minted & ženski & 3,51 & ,95 & $2,04^{\circ}$ & 309 \\
\hline 6 & 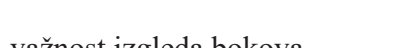 & muški & 3,13 & 1,21 & $106 * *$ & 260 \\
\hline 0. & vaznost izgieda bokova & ženski & 3,60 &, 89 & $-4,0$ & 309 \\
\hline 7 & עǎ̌nost izoleda ctrǎ̌niice & muški & 3,48 & 1,02 & $500 * *$ & 360 \\
\hline 1. & vazinost izgieda strazinflee & ženski & 3,99 &, 78 & $-2,09$. & 509 \\
\hline 8 & บǎ̌nost izoleda hedara & muški & 3,29 & 1,03 & 42 & 360 \\
\hline 0. & vaZirust ILgieda bedara & ženski & 3,75 &, 87 & $-4,20$ & 309 \\
\hline 0 & עǒ̌noct izoledo noout & muški & 3,53 & 1,09 & $356 * *$ & 360 \\
\hline 9. & vaziluse ilagicua nugu & ženski & 3,93 &, 87 & $-5,50$ & 305 \\
\hline 11 & vǎ̌nest izoledo trbuh & muški & 3,83 & 1,00 & 2 718* & 360 \\
\hline 11. &  & ženski & 4,09 &, 71 & $-2, / 10^{\circ}$ & 509 \\
\hline 12 & খ̌̌nost izolodo ctrutro & muški & 3,46 & 1,15 & k* & 360 \\
\hline 12. & Váznost izgieda struka & ženski & 3,97 &, 80 & $-4,005$ & 309 \\
\hline 13 & važnost izoleda ramena & muški & 3,79 & ,98 & $4352 * *$ & 369 \\
\hline & 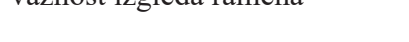 & ženski & 3,23 & 1,10 & 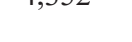 & \\
\hline 14 & važnost izoleda ruku & muški & 3,76 & 1,03 & $2355 *$ & 60 \\
\hline 17 . & 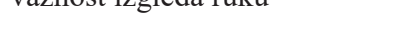 & ženski & 3,47 & ,99 & $2,5 J J^{2}$ & 303 \\
\hline
\end{tabular}

Napomena. $n=$ broj sudionika u poduzorcima; $M=$ aritmetička sredina; $S D=$ standardna devijacija; $t=\mathrm{t}$-test; $d f=$ stupnjevi slobode; $* p<, 05 ; * * p<, 001$. 
